\title{
Penerapan Model Problem Based Learning Untuk Meningkatkan Keterampilan Menyelesaikan Soal Cerita Pecahan
}

\author{
Mursolimah \\ SD Negeri 3 Sembukan \\ mursol82@yahoo.com
}

\section{Article History}

received 3/12/2020

revised 17/12/2020

accepted 31/12/2020

\begin{abstract}
The purpose of this research is to improve improve story fraction problem solving skill among $4^{\text {th }}$ grade students of SDN 3 Sembukan Sidoharjo Wonogiri in the academic year 2019/2020 by applying Problem Based Learning model. The research conducted was a Classroom Action Research (PTK). This research implemented in two cycles, each cycle consists of planning, acting, observing, and reflecting. The research result show that application of Problem Based Learning model can improve student's story fraction problem solving skill. The average of story fraction problem solving skill in the pre-cycle 55.93; cycle I 74.79; and cycle II 84.38. While classical completeness in pra-cycle was 4 students (26.67\%), cycle I was 12 students (80\%), cycle II was 15 students (100\%). The conclusion is application of Problem Based Learning model can improve story fraction problem solving skill among $4^{\text {th }}$ grade students of SDN 3 Sembukan Sidoharjo Wonogiri in the academic year 2019/ 2020.
\end{abstract}

Keywords: learning model, Problem Based Learning, story fraction problem solving skill

\begin{abstract}
Abstrak
Tujuan dari penelitian ini adalah untuk meningkatkan keterampilan menyelesaikan soal cerita pecahan pada siswa kelas IV SDN 3 Sembukan Sidoharjo Wonogiri tahun ajaran 2019/ 2020 dengan menerapkan model Problem Based Learning. Penelitian yang dilakukan adalah Penelitian Tindakan Kelas (PTK) Penelitian dilaksanakan dalam dua siklus, dengan tiap siklus terdiri atas perencanaan, pelaksanaan, observasi, dan refleksi. Hasil penelitian menunjukkan bahwa melalui penerapan model Problem Based Learning dapat meningkatkan keterampilan menyelesaikan soal cerita pecahan siswa. Adapun rata-rata keterampilan menyelesaikan soal cerita pada prasiklus 55,93; siklus I 74,79; dan siklus II 84,38. Sedangkan ketuntasan klasikal pada prasiklus sebanyak 4 peserta didik $(26,67 \%)$, siklus I sebanyak 12 peserta didik $(80 \%)$, siklus II sebanyak 15 peserta didik (100\%). Dengan demikian dapat disimpulkan bahwa penerapan model Problem Based Learning dapat meningkatkan keterampilan menyelesaikan soal cerita pecahan pada siswa kelas IV SDN 3 Sembukan Sidoharjo Wonogiri tahun ajaran 2019/ 2020.
\end{abstract}

Kata Kunci: model pembelajaran, Problem Based Learning, keterampilan menyelesaikan soal cerita pecahan

Social, Humanities, and Education Studies (SHEs): Conference Series https://jurnal.uns.ac.id/shes

p-ISSN 2620-9284

e-ISSN 2620-9292

This work is licensed under a Creative Commons Attribution-ShareAlike 4.0 International License. 


\section{PENDAHULUAN}

Sebagian besar siswa menganggap matematika merupakan pelajaran yang sulit dibandingkan pelajaran lain. Padahal sebenarnya, matematika tidak sesulit yang dibayangkan. Matematika selalu ditemui dalam kehidupan sehari-hari. Selain itu, pelajaran matematika sangat penting terutama untuk menanamkan proses berpikir logis, analitis, sistimatis, kritis, dan kreatif.

Matematika masuk ke dalam kelompok mata pelajaran IImu Pengetahuan dan Teknologi yang memiliki standar kompetensi untuk jenjang sekolah dasar dan sederajat yakni: 1) mengenal dan menggunakan berbagai informasi tentang lingkungan sekitar secara logis, kritis, dan kreatif; 2) menunjukkan ke-mampuan berpikir logis, kritis, dan kreatif dengan bimbingan guru/ pendidik; 3) menunjukkan rasa keingintahuan yang tinggi; 4) menunjukkan kemampuan memecahkan masalah sederhana dalam kehidupan sehari-hari; 5) menunjukkan kemampuan mengenali gejala alam dan sosial di lingkungan sekitar; 6) menunjukkan keterampilan menyimak, berbicara, membaca, menulis, dan berhitung; 7) menunjukkan kebiasaan hidup bersih, sehat, bugar, aman, dan memanfaakan waktu luang (Sanjaya, 2013: 82). Berdasarkan standar kompetensi tersebut, matematika harus mampu memecahkan masalah sederhana dalam kehidupan sehari-hari.

Salah satu materi yang tercantum dalam kurikulum mata pelajaran matematika di kelas IV sekolah dasar adalah pecahan. Pusat Pengembangan Kurikulum dan Sarana Pendidikan Badan Penelitian dan Pengembangan (Depdikbud, 1999) dalam Heruman (2012: 43) menyatakan bahwa pecahan merupakan salah satu topik yang sulit untuk diajarkan. Kesulitan itu terlihat dari kurang bermaknanya kegiatan pembelajaran yang dilakukan guru, dan sulitnya pengadaan media pembelajaran. Pada materi pecahan tersebut terdapat submateri menyelesaikan soal cerita pecahan.

Nafi'an menjelaskan "Berdasarkan keadaan di lapangan, masalah yang sering dirasakan sulit oleh siswa dalam pembelajaran matematika adalah menyelesaikan soal cerita. Keterampilan siswa menyelesaikan soal cerita dapat dilihat dari perolehan hasil belajar. Selain itu, dapat dilihat pula bagaimana siswa menyelesaikan soal cerita sampai menemukan jawaban yang benar" (2011: 571). Berdasarkan pendapat di atas, maka diperlukan cara pengajaran untuk memfasilitasi siswa dalam menyelesaikan soal cerita sesuai dengan langkah-langkah penyelesaian sampai menemukan jawaban yang benar.

Kenyataan di lapangan menunjukkan bahwa harapan akan penguasaan keterampilan menyelesaikan soal cerita pecahan belum sepenuhnya tercapai. Hal ini sesuai dengan hasil observasi yang dilakukan peneliti di kelas IV SDN 3 Sembukan Sidoharjo Wonogiri pada 12 Agustus 2019. Hasil observasi langsung dalam pembelajaran matematika di kelas IV menunjukkan hasil sebagai berikut: 1) guru cenderung dominan menggunakan metode ceramah dalam pembelajaran; 2) guru belum menggunakan media pembelajaran; 3) siswa bersikap pasif dalam pembelajaran, ditandai dengan hasil pengamatan aktivitas belajar siswa yang hanya mencapai skor 55,19 dan masuk kategori sangat kurang.

Hasil pengamatan di atas, dikuatkan hasil wawancara terhadap guru kelas dan siswa kelas IV pada 12 Agustus 2019 terungkap pula bahwa: 1) guru menerapkan metode pembelajaran yang menurutnya sesuai dan mudah diterapkan tanpa memandang apakah itu metode pembelajaran inovatif atau bukan; 2) media pembelajaran untuk materi pecahan susah diadakan; 3) siswa merasa pecahan adalah materi yang susah dipelajari.

Selain observasi dan wawancara, data hasil pretest siswa kelas IV yang dilakukan pada 12 Agustus 2019 juga menunjukkan bahwa keterampilan menyelesaikan soal cerita pecahan masih rendah. Dari 15 siswa, 11 atau 73,33 persen memperoleh nilai di bawah KKM yaitu $\geq 60$. Sedangkan 4 siswa lainnya atau 26,67 persen telah memenuhi KKM. Rata-rata kelas pada materi menyelesaikan soal cerita pecahan hanya mencapai 
55,93. Data tersebut menunjukkan bahwa hasil evaluasi materi menyelesaikan soal cerita pecahan belum memenuhi target seperti yang diharapkan.

Berdasarkan hasil pengamatan, wawancara, dan pretest pada 12 Agustus 2019 dapat diketahui bahwa faktor penyebab rendahnya penguasaan keterampilan menyelesaikan soal cerita pecahan antara lain: 1) guru belum menerapkan model pembelajaran inovatif; 2) susahnya pengadaan media pembe-lajaran membuat guru mengajar tanpa menggu-nakan media; 3) sebagian siswa merasa menyelesaikan soal ceritapecahan merupakan materi yang susah. Apabila hal tersebut tidak diatasi maka akan dapat menghambat siswa pada pembelajaran selanjutnya. Selain itu, jika anak terus mengalami kesulitan dan kebosanan dalam pembelajaran, maka dikhawatirkan anak akan frustasi dan enggan belajar sehingga prestasi belajarnya pun kurang memuaskan. Sehingga guru perlu mempertimbangkan model pembelajaran yang sesuai untuk mengatasi hal di atas.

Model pembelajaran merupakan suatu rancangan (desain) yang menggambarkan proses rinci penciptaan situasi lingkungan yang memungkinkan terjadinya interaksi pembelajaran agar terjadi perubahan atau perkembangan diri peserta didik (Sukmadinata \& Syaodih, 2012, hlm. 151). Saefuddin \& Berdiati menjelaskan, model pembelajaran adalah kerangka konseptual yang melukiskan prosedur sistematis dalam mengorganisasikan sistem belajar untuk mencapai tujuan belajar tertentu dan berfungsi sebagai pedoman bagi perancang pembelajaran dan para pengajar dalam merencanakan dan melaksanakan aktivitas pembelajaran (2014, hlm. 48). Definisi tersebut senada dengan pendapat Suprihatiningrum (2013, hlm. 145) yang menyatakan bahwa model pembelajaran adalah kerangka konseptual yang melukiskan prosedur pembelajaran dengan sistematis untuk mengelola pengalaman belajar siswa agar tujuan belajar tertentu yang diinginkan bisa tercapai. Jadi, model pembelajaran adalah kerangka kerja yang memberikan gambaran sistematis untuk melaksanakan pembelajaran agar membantu belajar siswa dalam tujuan tertentu yang ingin dicapai.

Model pembelajaran merupakan penyebab utama masalah di atas. Model pembelajaran yang digunakan dalam pembelajaran masih berpusat pada guru, dengan lebih sering menggunakan metode ceramah dan belum menggunakan media pembelajaran yang sesuai. Hal tersebut menyebabkan siswa kurang aktif. Oleh karena itu, perlu dilakukan adanya tindakan untuk memperbaiki proses pembelajaran yang demikian. Peneliti memilih model Problem Based Learning untuk diterapkan sebagai alternatif pemecahan masalah di atas.

Problem Based Learning merupakan model pembelajaran yang mengembangkan konsep belajar penemuan atau discovery learning yang dicetuskan oleh Jerome Bruner (Suprijono, 2014: 68). Fokusnya adalah aktivitas penyelidikan masalah. Pada awal pembelajaran telah ditentukan sebuah masalah berupa informasi yang disampaikan guru pada siswa. Lalu siswa akan melakukan analisis tentang masalah tersebut agar menemukan sesuatu untuk dilaporkan. Penyajian laporan harus mengandung solusi dan refleksi dari permasalahan. Dan pada akhir pembelajaran akan ditarik kesimpulan serta dilakukan evaluasi untuk mengetahui tingkat ketercapaian dari tujuan pemecahan masalah.

Pembelajaran berbasis masalah meliputi pengajuan pertanyaan atau masalah, memusatkan pada keterkaitan antar disiplin, penyelidikan asli/ autentik, kerjasama dan menghasilkan karya serta peragaan. (Muhtadi, 2019: 22). Problem Based Learning mendorong siswa untuk belajar aktif dalam menggunakan konsep-konsep untuk memecahkan masalah. Siswa dapat memanfaatkan berbagai pengalaman yang telah dimilikinya untuk menemukan konsep baru berdasarkan penyelidikannya. Sehingga siswa bukan hanya menerima materi dan informasi dari guru, melainkan dengan usahanya sendiri serta berdasarkan pengetahuan dan keterampilan yang telah dimiliki sebelumnya untuk diintegrasikan dengan pengetahuan dan keterampilan yang baru diperoleh. Problem Based Learning dapat digunakan pula dalam mencapai tujuan yang 
berkaitan dengan belajar keterampilan pemecahan masalah. Hal tersebut membuat PBL cocok diterapkan dalam pembelajaran materi menyelesaikan soal cerita pecahan yang membutuhkan sebuah kegiatan pembelajaran bermakna.

Sehubungan dengan masalah tersebut, dapat dirumuskan masalah, yaitu: apakah penerapan model Problem Based Learning dapat meningkatkan keterampilan menyelesaikan soal cerita pecahan pada siswa kelas IV SDN 3 Sembukan Sidoharjo Wonogiri Tahun Ajaran 2019/ 2020? Adapun tujuan penelitian ini yaitu untuk meningkatkan keterampilan menyelesaikan soal cerita pecahan dengan menerapkan model Problem Based Learning pada siswa kelas IV SDN 3 Sembukan Sidoharjo Wonogiri Tahun Ajaran 2019/ 2020.

\section{METODE}

Penelitian Tindakan Kelas ini dilaksanakan di SDN 3 Sembukan Sidoharjo Wonogiri. Subjek penelitian ini adalah guru kelas dan siswa kelas IV yang berjumlah 15 siswa. Waktu penelitian berlangsung selama lima bulan yaitu Agustus hingga Desember tahun 2019. Sumber data dalam penelitian ini antara lain: 1) informasi dari narasumber yang terdiri atas guru dan siswa kelas V; 2) dokumen berupa data silabus, RPP, foto dan video dalam pelaksanaan pembelajaran; 3) arsip nilai siswa; 4) hasil pengamatan pelaksanaan pembelajaran dengan menggunakan model Problem Based Learning.

Teknik pengumpulan data yang digunakan dalam penelitian ini yaitu wawancara, observasi, dokumentasi, dan tes. Wawancara dilakukan untuk mengetahui informasi tentang hal-hal yang berkaitan dengan pembelajaran matematika di SDN 3 Sembukan Sidoharjo Wonogiri seperti cara guru mengajar, model pembelajaran yang digunakan, dan keadaan siswa saat pembelajaran berlangsung, khususnya pada keterampilan menyelesaikan soal cerita pecahan. Observasi dilakukan untuk mengukur dan menilai kemampuan guru dalam menerapkan Problem Based Learning serta aktivitas belajar siswa saat pembelajaran. Dokumentasi dilakukan untuk mengumpulkan data dan arsip seperti silabus, RPP, foto, dan video pembelajaran, serta daftar nilai keterampilan menyelesaikan soal cerita pecahan siswa. Dalam penelitian ini digunakan tes untuk mengumpulkan data nilai tentang keterampilan menyelesaikan soal cerita pecahan siswa. Tes diberikan setiap akhir pembelajaran, berupa tes tertulis dengan bentuk uraian.

Validitas data dalam penelitian ini diuji dengan menggunakan triangulasi sumber dan triangulasi metode. Teknik analisis data yang digunakan adalah model analisis interaktif yang terdiri atas reduksi data, penyajian, dan penarikan kesimpulan. Selain itu, juga digunakan teknik analisis deskriptif komparatif untuk menganalisis data kuantitatif dan teknik analisis kritis untuk menganalisis data kualitatif.

Dalam penelitian tindakan kelas ini, menggunakan prosedur penelitian model spiral saling berkaitan yang terdiri atas siklus-siklus tindakan. Tiap siklus terdiri atas empat tahapan, yaitu perencanaan (menggambarkan secara rinci hal-hal yang perlu dipersiapkan sebelum tindakan), pelaksanaan tindakan (melaksanakan pembelajaran sesuai dengan rancangan), observasi (mengamati dan menginterpretasi aktivitas penerapan tindakan), dan refleksi (dilakukan setelah semua data terkemupul).

\section{HASIL DAN PEMBAHASAN}

Berdasarkan hasil wawancara, observasi, dan pretest yang dilakukan peneliti pada kelas IV SDN 3 Sembukan Sidoharjo tahun pelajaran 2019/2020, menunjukkan bahwa keterampilan menyelesaikan soal cerita pecahan masih rendah. Hasil pretest yang dilakukan sebagian besar peserta didik belum mencapai $K K M$ sebesar $\geq 60$, yaitu sebanyak 11 peserta didik. Hanya 4 peserta didik yang dapat mencapai KKM sebesar $\geq 60$. Hasil selengkapnya dapat dilihat pada Tabel 1 sebagai berikut 
Tabel 1. Frekuensi Data Nilai Keterampilan Menyelesaikan Soal Cerita Pecahan

\begin{tabular}{lcccc}
\multicolumn{5}{c}{ Pra-siklus } \\
\hline Interval & $x_{i}$ & $f_{i}$ & $f_{i} \cdot x_{i}$ & Persentase \\
\hline $47-51$ & 49,5 & 4 & 198 & $26,67 \%$ \\
$52-56$ & 54,5 & 2 & 109 & $13,33 \%$ \\
$57-61$ & 59,5 & 5 & 297,5 & $33,33 \%$ \\
$62-66$ & 64,5 & 2 & 129 & $13,33 \%$ \\
$67-71$ & 69,5 & 2 & 139 & $13,33 \%$ \\
Jumlah & & 15 & 872,5 & $100 \%$ \\
Nilai Tertinggi & & & & 67 \\
Nilai Terendah & & & & 47 \\
Rata-rata Kelas & & & 55,93 \\
Ketuntasan Klasikal & & & $26,67 \%$ \\
\hline
\end{tabular}

Berdasarkan data pada Tabel 1, menunjukkan bahwa sebanyak 11 peserta didik atau $73,33 \%$ belum mencapai KKM sebesar $\geq 60$, sedangkan 4 siswa sebanyak $26,67 \%$ telah mencapai KKM sebesar $\geq 60$. Nilai rata-rata kelas sebesar 55,93 . Adapun skor hasil pengamatan aktivitas peserta didik prasiklus diperoleh rata-rata kelas sebesar 4 kategori kurang baik (KB).

Pelaksanaan pembelajaran menyelesaikan soal cerita pecahan siklus I, dilakukan tindakan yaitu dengan menerapkan model Problem Based Learning. Setelah dilakukan tindakan siklus I terjadi peningkatan keterampilan menyelesaikan soal cerita pecahan. Hasil selengkapnya dapat dilihat pada Tabel 2 sebagai berikut:

Tabel 2. Frekuensi Data Nilai Keterampilan Menyelesaikan Soal Cerita Pecahan Siklus I

\begin{tabular}{lcccc}
\hline Interval & $x_{i}$ & $f_{i}$ & $f_{i} \cdot x_{i}$ & Persentase \\
\hline $50-59$ & 54,5 & 3 & 163,5 & $20 \%$ \\
$60-69$ & 64,5 & 2 & 129 & $13,33 \%$ \\
$70-79$ & 74,5 & 3 & 223,5 & $20 \%$ \\
$80-89$ & 84,5 & 7 & 591,5 & $46,67 \%$ \\
Jumlah & & 15 & 1107,5 & $100 \%$ \\
Nilai Tertinggi & & & & 88,13 \\
Nilai Terendah & & & & 55,63 \\
Rata-rata Kelas & & & 74,79 \\
Ketuntasan Klasikal & & & $80 \%$ \\
\hline
\end{tabular}

Berdasarkan data pada Tabel 2, menunjukkan bahwa peserta didik yang telah berhasil mencapai $\mathrm{KKM} \geq 60$ sebanyak 12 peserta didik atau $80 \%$, sedangkan 3 peserta didik atau $20 \%$ belum mencapai KKM sebesar $\geq 60$. Sedangkan rata-rata kelas 74,79 . Akan tetapi, indikator kinerja sebanyak $100 \%$ peserta didik memperoleh nilai sebesar $\geq 60$ belum tercapai. Selain data nilai keterampilan menyelesaikan soal cerita pecahan, aktivitas peserta didik selama pembelajaran pun diamati. Berdasarkan hasil pengamatan aktivitas peserta didik selama pada siklus I diperoleh rata-rata kelas sebesar 17 termasuk kategori (B). Artinya aktivitas peserta didik selama pembelajaran siklus I sudah menunjukkan keaktifan dalam pembelajaran.

Selanjutnya, untuk perbaikan dan peningkatan pelaksanaan pembelajaran menyelesaikan soal cerita pecahan dengan menerapkan model Problem Based Learning siklus I dilaksanakan pada siklus II. Setelah dilaksanakan pembelajaran siklus II dengan menerapkan model Problem Based Learning menunjukkan peningkatan nilai keterampilan menyelesaikan soal cerita pecahan. Hasil selengkapnya dapat dilihat pada Tabel 3 sebagai berikut. 
Tabel 3. Frekuensi Data Nilai Keterampilan Menyelesaikan Soal Cerita Pecahan Siklus II

\begin{tabular}{lcccc}
\hline Interval & $x_{i}$ & $f_{i}$ & $f_{i} \cdot x_{i}$ & Persentase \\
\hline $61-70$ & 65,5 & 3 & 196,5 & $20 \%$ \\
$71-80$ & 75,5 & 1 & 75,5 & $6,67 \%$ \\
$81-90$ & 85,5 & 4 & 342 & $26,67 \%$ \\
$91-100$ & 95,5 & 7 & 668,5 & $46,67 \%$ \\
Jumlah & & 15 & 1282,5 & $100 \%$ \\
Nilai Tertinggi & & & & 100 \\
Nilai Terendah & & & & 61,88 \\
Rata-rata Kelas & & & 84,38 \\
Ketuntasan Klasikal & & & $100 \%$ \\
\hline
\end{tabular}

Berdasarkan data pada Tabel 3, menunjukkan bahwa peserta didik yang telah berhasil mencapai KKM sebesar $\geq 60$ sebanyak 15 peserta didik atau $100 \%$. Artinya keseluruhan peserta didik telah mampu mencapai KKM yang telah ditetapkan sebesar $\geq 60$. Hal tersebut menandakan pula, indikator kinerja dapat tercapai. Hasil yang diperoleh menunjukkan peningkatan dibandingkan pada siklus I. Skor hasil pengamatan aktivitas peserta didik siklus II diperoleh skor rata-rata kelas sebenar 23 termasuk kategori sangat baik (SB). Data tersebut menunjukkan bahwa aktivitas peserta didik selama pembelajaran menyelesaikan soal cerita pecahan dengan menerapkan model Problem Based Learning mengalami peningkatan yang signifikan.

Berdasarkan data-data yang telah diperoleh menunjukkan bahwa keterampilan menyelesaikan soal cerita pecahan serta aktivitas peserta didik kelas IV SDN 3 Sembukan Sidoharjo pada siklus II mengalami peningkatan. Selain itu, indikator kinerja sebesar $100 \%$ peserta didik mencapai KKM yang telah ditentukan yaitu $\geq 60$. Artinya keseluruhan peserta didik kelas IV yaitu 15 anak telah mencapai KKM sebesar $\geq 60$. Serta pengamatan aktivitas belajar peserta didik pun termasuk dalam kategori sangat baik (SB). Oleh karena itu, penelitian ini dihentikan pada siklus II.

Data-data yang telah diperoleh dari prasiklus, siklus I, dan siklus II dikaji sesuai dengan rumusan masalah dan selanjutnya dikaitkan dengan teori yang telah dikemukakan. Berdasarkan hasil observasi, tes, dan analisis data, penelitian ini menunjukkan adanya peningkatan nilai keterampilan menyelesaikan soal cerita pecahan serta aktivitas peserta didik dalam pembelajaran menyelesaikan soal cerita pecahan dengan menerapkan model Problem Based Learning pada peserta didik kelas IV SDN 3 Sembukan Sidoharjo tahun ajaran 2019/2020 pada setiap siklus. Peningkatan nilai keterampilan menyelesaikan soal cerita pecahan serta ativitas peserta didik pada penelitian ini terjadis secara bertahap. Peningkatan tersebut dapat dilihat pada Tabel 5 sebagai berikut.

Tabel 5. Data Peningkatan Keterampilan Menyelesaikan Soal Cerita Pecahan serta Aktivitas Peserta Didik Prasiklus, Siklus I, dan Siklus II

\begin{tabular}{cccc}
\hline Aspek & Prasiklus & Siklus I & Siklus II \\
\hline Rata-rata Kelas & 55,93 & 74,79 & 84,38 \\
$\quad$ Tuntas & 4 & 12 & 15 \\
Tidak Tuntas & 11 & 3 & - \\
$\begin{array}{c}\text { Ketuntasan } \\
\text { Klasikal }\end{array}$ & $26,67 \%$ & $80 \%$ & $100 \%$ \\
$\begin{array}{c}\text { Aktivitas Peserta } \\
\text { Didik }\end{array}$ & 4 & 17 & 23 \\
$\begin{array}{c}\text { Skor Rata-Rata } \\
\text { Kelas }\end{array}$ & Kurang Baik & Baik & Sangat Baik \\
\hline
\end{tabular}


Berdasarkan Tabel 5 menunjukkan bahwa penerapan model Problem Based Learning dapat meningkatkan keterampilan menyelesaikan soal cerita pecahan pada siswa kelas IV SDN 3 Sembukan Sidoharjo tahun ajaran 2019/2020. Hasil penelitian ini juga sesuai dengan penelitian sebelumnya yang dilakukan oleh Dewi Fitriana (2015) yang membuktikan bahwa penerapan model Problem Based Learning dapat meningkatkan kemampuan pemecahan masalah matematika siswa pada materi soal cerita bilangan pecahan.

Keberhasilan dalam suatu pembelajaran dapat ditandai dengan pembelajaran yang bermakna. Model Problem Based Learning dapat memberikan pembelajaran bermakna karena siswa dilatih untuk berusaha mencari pemecahan masalah secara mandiri yang akan memberikan pengalaman nyata. Menurut Trianto (2011: 67), karena pengalaman itu memberikan makna tersendiri bagi peserta didik maka peserta didik dapat menggunakan pengalaman tersebut untuk memecahkan permasalahan yang serupa. Sehingga, jika satu permasalahan dapat diselesaikan oleh peserta didik, maka peserta didik dapat menggunakan cara yang sama apabila menemui permasalahan yang serupa. Seperti halnnya pada soal matematika yang bervariasi tetapi sebenarnya memiliki cara yang sama untuk menyelesaikannya, khususnya materi pecahan.

\section{SIMPULAN}

Berdasarkan hasil penelitian tindakan kelas yang telah dilakukan dalam dua siklus selama empat kali pertemuan, disimpulkan bahwa penerapan model Problem Based Learning terbukti dapat meningkatkan keterampilan menyelesaikan soal cerita pecahan pada siswa kelas IV SDN 3 Sembukan Sidoharjo Wonogiri tahun ajaran 2019/2020. Hal tersebut ditunjukkan dengan adanya peningkatan nilai rata-rata kelas dari kondisi awal hingga siklus II. Rata-rata keterampilan menyelesaikan soal cerita pecahan pada prasiklus 55,93; siklus I 74,79; dan siklus II 84,38. Ketuntasan klasikal pada prasiklus sebanyak 4 peserta didik (26,67\%), siklus I sebanyak 12 peserta didik (80\%), siklus II sebanyak 15 peserta ddik (100\%). Sedangkan skor rata-rata aktivitas peserta didik pada prasiklus sebesar 4 termasuk kategori kurang baik; siklus I sebesar 17 termasuk kategori baik, dan siklus II sebesar 23 termasuk kategori sangat baik. Dengan demikian, secara klasikal kemampuan menyelesaikan soal cerita pecahan telah mencapai indikator kinerja sebesar $100 \%$ peserta didik mencapai KKM ( $\geq 60)$. Sehingga hasil tersebut dapat memenuhi indikator kinerja penelitian.

\section{DAFTAR PUSTAKA}

Fitriana, Dewi. (2015). Penerapan Model Problem Based Learning untuk Peningkatan Kemampuan Pemecahan Masalah Matematika Siswa pada Materi Soal Cerita Bilangan Pecahan. Skripsi Program Studi Pendidikan Guru Sekolah Dasar, Fakultas Keguruan dan Ilmu Pendidikan, Universitas Muria Kudus. Retrieved from http://eprints.umk.ac.id/

Heruman. (2012) Model pembelajaran matematika di sekolah dasar. Bandung: Remaja Rosdakarya.

Muhtadi, Ali. (2019). Pembelajaran Inovatif. Jakarta: Kementerian Pendidikan dan Kebudayaan.

Nafi'an, M.I. (2011). Kemampuan Siswa dalam Menyelesaikan masalah soal cerita Ditinjau Dari Gender di Sekolah Dasar. Prosiding Makalah Seminar Nasional Matematika dan Pendidikan Matematika, hlm. MP-571 - MP-577. Yogyakarta. FMIPA Universitas Negeri Yogyakarta.

Saefuddin, A. \& Berdiati, I. (2014). Pembelajaran Efektif. Bandung: PT Remaja Rosdakarya.

Sanjaya, W. (2013). Strategi Pembelajaran Berorientasi Standar Proses Pendidikan. Jakarta: Kencana Prenadamedia Group. 
SHEs: Conference Series 3 (4) (2020) 180 - 187

Sukmadinata, N.S. \& Syaodih, E. (2012). Kurikulum dan Pembelajaran Kompetensi. Bandung: PT Refika Aditama.

Suprihatiningrum, Jamil (2013). Strategi Pembelajaran. Yogyakarta: Ar-ruzz Media.

Suprijono, A. (2014). Cooperative Learning. Yogyakarta: Pustaka Pelajar.

Trianto. (2011). Model-model Pembelajaran Inovatif Berorientasi Konstruktivistik. Jakarta: Prestasi Pustaka. 